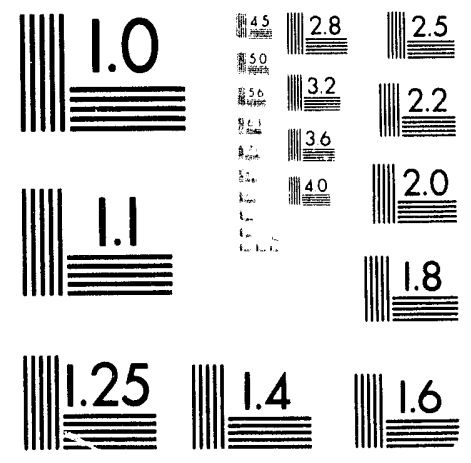



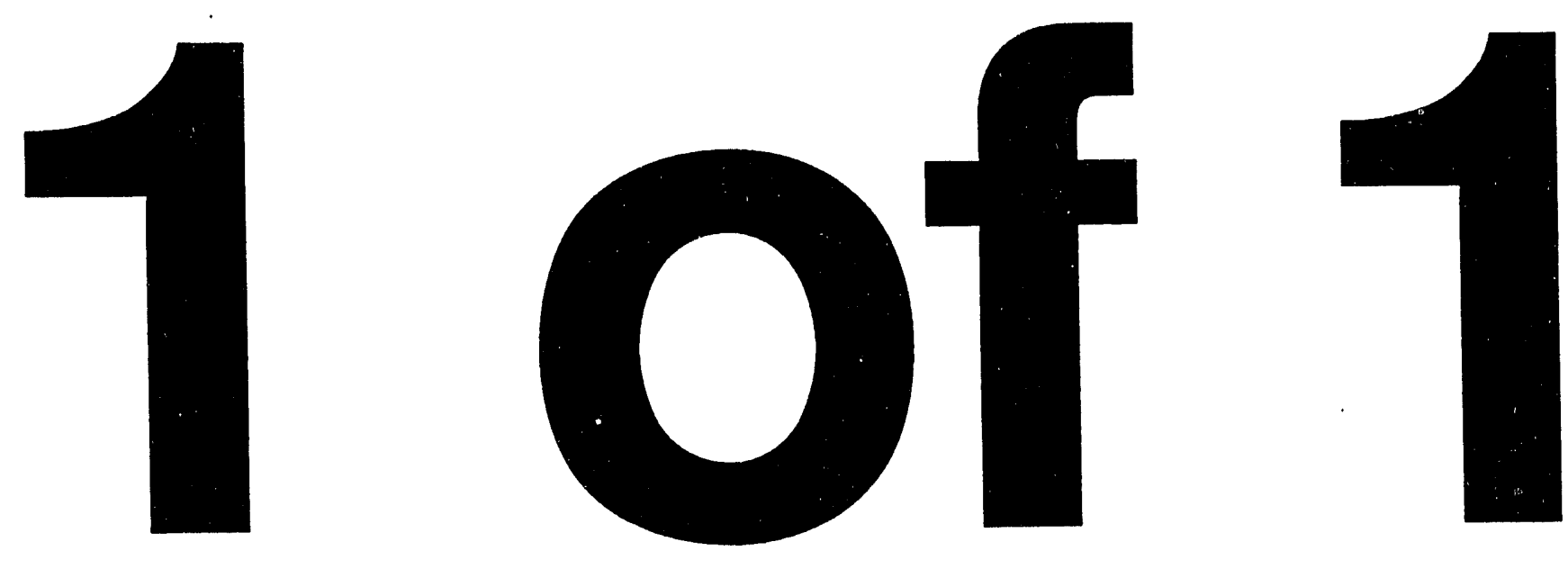
DOE/EA - 0873

\section{ENVIRONMENTAL ASSESSMENT \\ FOR THE \\ HEALTH PROTECTION \\ INSTRUMENT CALIBRATION FACILITY \\ AT THE \\ SAVANNAH RIVER SITE}

AUGUST 1993

\section{MASTER}

UNITED STATES DEPARTMENT OF ENERGY, SAVANNAH RIVER OPERATIONS OFFICE AIKEN, SOUTH CAROLINA

DISTRIBUTION OF THIS DOCUMENT IS UNLIMITED DISTRIBUTION OF THIS DOCUMENT IS ON 
TABLE OF CONTENTS

INTRODUCTION

1.0 PURPOSE AND NEED FOR ACTION

2.0 PROPOSED ACTION AND ALTERNATIVES 3

2.1 Proposed Action 3

2.1.1 Facility and Process Description 3

2.1.1.1 Materials 3

2.1.1.2 Facility

2.1.1.3 Process 5

2.2 Alternative Actions 5

2.2.1 No Action 5

2.2.2 Renovation of Existing Instrument Calibration Facility 5

2.2.3 Expansion of Existing Instrument Calibration Facility 6

2.2.4 Alternative Construction Sites 6

2.2.5 Use of Offsite Calibration Facilities 6

3.0 AFFECTED ENVIRONMENT

3.1 Geography, Demography and Socioeconomics 7

3.2 Meteorology and Climatology 7

3.2.1 Average Wind Speed and Direction 7

3.2 .2 Precipitation 10

3.2 .3 Tornadoes 10

$\begin{array}{lll}3.3 \text { Geology and Seismology } & 10\end{array}$

3.3.1 Physiography 10

3.3.2 Topography and Drainage $\quad 10$

3.3.3 Geohydrology 10

3.3.4 Geologic Structures 11

3.4 Hydrology 11

3.5 Ecology 11

3.5.1 Vegetation 12

$\begin{array}{ll}3.5 .2 \text { Wildlife } & 12\end{array}$

3.5.2.1 Threatened and Endangered Species $\quad 12$

3.6 Radiation Environment 13

3.7 Waste Management 13 
TABLE OF CONTENTS (Cont'd)

Page

4.0 ENVIRONMENTAL CONSEQUENCES OF THE PROPOSED ACTION

4.1 Construction and Normal Operation 14

4.1.1 Land 14

4.1.2 Socioeconomics 14

4.1.3 Air Quality 14

4.1.4 Groundwater and Surface-Water Resources 15

4.1.5 Waste Management 15

4.1.6 Radioactive and Hazardous Materials 16

4.1.7 Archaeological and Cultural Resources 17

$\begin{array}{ll}4.1 .8 \text { Ecology } & 17\end{array}$

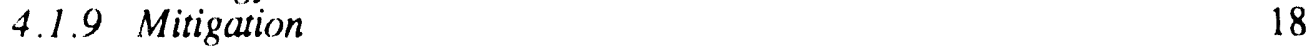

4.2 Accident Analysis 18

4.2 .1 Non-radiological Consequences 18

4.2.2 Radiological Consequences 18

4.3 Cumulative Impact 20

5.0 REGULATORY AND PERMITTING PROVISIONS
CONSIDERED

5.1 National Environmental Policy Act of 1969

5.2 Solid Waste Regulations 22

5.3 Air Emissions Regulations 22

5.4 Domestic Water Regulations 22

5.5 Liquid Discharge Regulations 22

5.6 Transportation Regulations 23

6.0 AGENCIES AND PERSONNEL CONSULTED 23

7.0 REFERENCES 24 


\section{LIST OF TABLES}

Number

Table 2-1. Radiological Calibration Sources and Quantities

Table 4-1. Hazardous Chemicals/Materials

Table 42. Potential Criticality Hazard Sources

Table 4-3. Radiological Dose from Accident

Table 4-4. Summary of Potential Impacts

\section{LIST OF FIGURES}

Number

Page

Figure 3-1. SRS in Relation to Surrounding Population Centers

Figure 3-2. Location of B Area on SRS

9

Figure 3-3. SRS Regional Radiological Dose 


\section{INTRODUCTION}

r

The purpose of this Environmental Assessment (EA) is to review the possible environmental consequences associated with the construction and operation of a Health Protection Instrument Calibration Facility on the Savannah River Site (SRS). The proposed replacement calibration faci'ity would be located in B Area of SRS and would replace an inadequate existing facility currently located within A Area of SRS (Building 736-A). The new facility would provide laboratories, offices, test equipment and the support space necessary for the SRS Radiation Monitoring Instrument Calibration Program to comply with DOE Orders 5480.4 (Environmental Protection, Safety and Health Protection Standards) and 5480.11 (Radiation Protection for Occupi tional Workers). The proposed facility would serve as the central site source for the evaluation, selection, inspection, testing, calibration, and maintenance of all SRS radiation monitoring instrumentation.

The proposed action has independent utility to SRS operations and would be necessary to support plant activities regardless of the makeup of the mission at SRS. As such, the proposed Health Protection Instrument Calibration Facility is treated as part of the preliminary Reconfiguration Programmatic Environmental Impact Statement (EIS) "No Action" alternative (DOE, 1991).

In accordance with National Environmental Policy Act (NEPA) regulations, the Department of Energy (DOE) has examined five alternative actions to the proposed action. These alternative actions include;

- No Action

- Renovation of the Existing Calibration Facility

- Expansion of the Existing Calibration Facility

- Alternative Construction Sites

- Use of Offsite Calibration Facilities

The proposed facility would be constructed on a currently undeveloped portion in B Area of SRS. The exact plot associated with the proposed action is a 1.2 hectare ( 3 acre) tract of land located on the west side of SRS Road \#2. The proposed facility would lie approximately $4.4 \mathrm{~km}(2.75 \mathrm{mi})$ from the nearest SRS site boundary. The proposed facility would also lie within the confines of the existing B Area, and SRS safeguards and security systems. Archaeological, ecological, and land use reviews have been conducted in connection with the use of this proposed plot of land, and a detailed discussion of these reviews is contained herein. Socioeconomic, operational, and accident analyses were also examined in relation to the proposed project and the findings from these reviews are also contained in this EA.

\subsection{PURPOSE AND NEED FOR ACTION}

The Department of Energy's (DOE) primary mission at SRS includes the processing of nuclear materials for the United States Government. In order to safely accomplish this mission, it is imperative that the measuring instruments used to monitor radiation be accurate, reliable and readily available. In order to ensure that this support equipment (i.e., radiation measuring instrumentation) is properly calibrated and maintained, it is imperative that an adequate calibration facility be made available to SRS.

An adequate facility would provide for the calibration services, testing, maintenance and inspection of radiation monitoring instrumentation. This project would also provide all of the laboratories, offices, and test equipment necessary for the SRS Instrument Calibration Program to comply with DOE Orders 5480.4 and 5480.11 . 
The existing SRS calibration facility is located within A Area of SRS in building 736-A. This aging facility was constructed in 1952 and is no longer capable of supporting the growing number and complexity of the detection instruments currently being fielded at SRS. Compliance with DOE orders necessitates a modern, state-of-the-art facility which is capable of performing its mission in a timely and reliable manner. Dosimetry records from 736-A show that calibration technicians are not currently capable of complying with the SRS As Low As Reasonably Achievable (ALARA) goals and have received doses as high as 145 mrem $^{\text {* }}$ per month and occasionally must stand in radiation fields as high as $1,2(1) \mathrm{mrem} / \mathrm{hr}$. The $736-\mathrm{A}$ facility is currently not capable of complying with DOE Orders 5480.4 and 5480.11, or American National Standards Institute (ANSI) N323 (Radiation Instrument Test and Calibration) and 13.6 (Practice for Occupational Radiation Exposure Record System), per DOE Order 548(1.4. Some of the areas of specific noncompliance are;

- The 736-A facility cannot accommodate radiation sources of sufficient strength to test and calibrate high range gamma instruments in accordance with ANSI N323.

- The 736-A facility has neither an $x$-ray laboratory for low energy instrument calibrations nor a beta beam calibration capability. Exposure rates in some parts of SRS are due primarily to these two forms of radiation.

- The 736-A facility does not have a low scattering laboratory for performing primary calibrations of gamma and neutron instruments and for determining extracameral response ${ }^{b}$.

- Space limitations force the use of source-to-detector distances that are too small to ensure uniform radiation fields across photon and neutron monitoring instruments.

- The existing facility does not meet the necessary standards to qualify for accreditation by the National Voluntary Laboratory Accreditation Program (NVLAP), as administered by the National Institute of Standards and Technology. Receipt of NVLAP Accreditation is considered necessary to establish the credibility of the SRS Instrument Calibration Program.

The noncompliance issues listed above were noted by a Department of Energy, Headquarters (DOE-HQ) Tiger Team finding (SRL/RP.8-2), which stated that the long-term correction to the existing noncompliance with ANSI N323 requirements for calibration of high range instruments would be addressed through the design and construction of a new Instrument Calibration Facility. The need for a new facility and improved calibration practices was also specifically addressed by DOE-HQ, Office of Environmental, Safety and Health during a review conducted on the SRS Health Physics Program in 1988 (Ferlic et al., 1989).

a mrem: The millirem $=1 / 1(K) 0 \mathrm{rem}$. The rem is a unit of radiation dose which takes into account the energy deposited in the body and the effectiveness of that energy to produce a biological effect. One rem of ionizing radiation will produce a biological effect approximately equal to that produced by one rexentgen of $x$-ray or gamma radiation.

b This refers to the effects of radiation on those parts of a monitoring instrument other than the actual detector. Specifically related to the effects of radiation on an instrument's electronics. 


\subsection{PROPOSED ACTION AND ALTERNATIVES}

\subsection{Proposed Action}

The proposed action is to construct and operate a new Heaith Protection Instrument Calibration Facility in B Area of SRS. The proposed facility would provide the laboratories, offices, equipment, and support space necessary for the SRS Instrument Calibration Program to be in compliance with applicable DOE orders and ANSI standards. The proposed action also represents a commitment made in the DOE-approved SRS Implementation Plan for DOE Order 5480.11.

The proposed calibration facility would be designed and constructed in accordance with DOE Order 6430.1A. This project has been determined to be in the Production Support (PS) design class. This classification applies to systems which handle radioactive materials, but which are not classified as nuclear safety class. The PS design category includes emergency response to all potential radioactive or hazardous chemical releases.

A Hazards Assessment has been conducted in accordance with the Interim Hazards Guide for Non-Reactor Facilities at the Savannah River Site (WSRC, 1990) and is documented in the Functional Design Criteria. The proposed calibration facility has been classified as a General Support Nonnuclear Facility. The Facility Segment Use Category of the proposed calibration facility was determined to be General Use (Nadaeu, 1993). All applicable safety requirements of DOE orders and SRS standards and specifications would be incorporated in accordance with DOE requirements.

In addition to the physical construction of the proposed calibration facility this fiscal year 1992 line item project would also provide all laboratory calibration, repair and test equipment necessary to bring SRS into compliance with DOE orders. The total estimated cost for this project is currently set at $\$ 20.6$ million dollars. Current project schedules have slated construction for this facility to begin in February 1994.

\subsubsection{Facility and Process Description}

\subsubsection{Materials}

The primary mission of the proposed calibration facility would be the inspection, calibration and maintenance of the radiation monitoring instruments used on SRS. In order to accomplish this mission it would be necessary for the proposed Health Protection Instrument Calibration Facility to maintain a number of radiation sources within the facility. The sources would include potentially hazardous amounts of radioactive materials including cobalt $-60\left({ }^{60} \mathrm{Co}\right)$; strontium- $90\left({ }^{90} \mathrm{Sr}\right)$; cesium-137 $\left({ }^{137} \mathrm{Cs}\right)$; promethium$147\left({ }^{147} \mathrm{Pm}\right)$; thallium-204 $\left({ }^{204} \mathrm{Tl}\right)$; californium-252 $\left({ }^{252} \mathrm{Cf}\right)$; tritium $\left({ }^{3} \mathrm{H}\right)$; and plutonium-239 $\left({ }^{239} \mathrm{Pu}\right)$. A complete listing of the source materials and their strength is listed in Table 2-1.

\subsubsection{Facility}

Preliminary designs (Title I) call for the proposed facility to be located in the northwest corner of B Area at SRS. This area was chosen for its central location on SRS and ease of access from all supported areas. The proposed facility would be a 22,000 square foot single story structure built on grade.

The majority of the exterior walls would be constructed of concrete block with an insulated metal panel roof. The interior walls would normally be gypsum board or concrete block. However, poured concrete would be utilized in those areas where radiation shielding was required. Some laboratories would require wells or pits as deep as 20 feet below grade for radiation source positioning and storage. The facility would have 50 paved parking spaces to accommodate employee, facility, and visitor vehicles. 
Table 2-1

Radiological Calibration Sources and Quantities for the Proposed Instrument Calibration Facility.

\begin{tabular}{|c|c|c|}
\hline NUCLIDE & $\begin{array}{l}\text { MAXIMUM } \\
\text { ACTIVITY }\end{array}$ & LOCATION \\
\hline $\begin{array}{l}{ }^{60} \mathrm{Co} \\
60 \mathrm{Co} \\
60 \mathrm{Co} \\
{ }^{137} \mathrm{Cs} \\
137 \mathrm{Cs} \\
137 \mathrm{Cs}\end{array}$ & $\begin{array}{c}\text { SEALED SOURCES } \\
6,000 \mathrm{Ci}(*) \\
600 \mathrm{Ci} \\
60 \mathrm{Ci} \\
5,000 \mathrm{Ci} \\
500 \mathrm{Ci} \\
50 \mathrm{Ci}\end{array}$ & $\begin{array}{l}\text { Gamma Beam Room } \\
\text { Gamma Beam Room } \\
\text { Gamma Beam Room } \\
\text { Gamma Beam Room } \\
\text { Gamma Beam Room } \\
\text { Gamma Beam Room }\end{array}$ \\
\hline $\begin{array}{l}{ }^{60} \mathrm{Co} \\
137 \mathrm{Cs} \\
137 \mathrm{Cs} \\
137 \mathrm{Cs} \\
252 \mathrm{Cf} \\
252 \mathrm{Cf} \\
252 \mathrm{Cf}\end{array}$ & 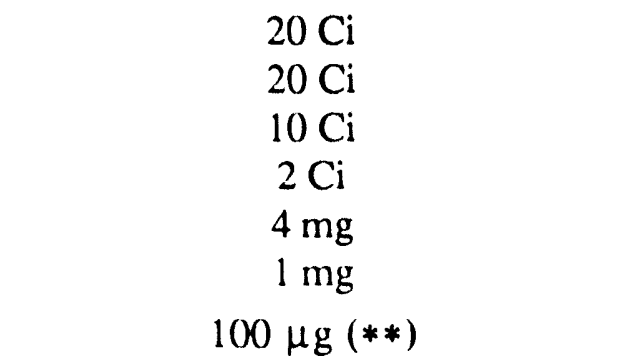 & $\begin{array}{l}\text { Low Scatter Room } \\
\text { Low Scatter Room } \\
\text { Low Scatter Room } \\
\text { Low Scatter Room } \\
\text { Low Scatter Room } \\
\text { Low Scatter Room } \\
\text { Low Scatter Room }\end{array}$ \\
\hline${ }^{137} \mathrm{Cs}$ & $1.2 \mathrm{Ci}$ & Panoramic Irradiator \\
\hline $\begin{array}{l}90 \mathrm{Sr} / \mathrm{Y} \\
147 \mathrm{Pm} \\
204 \mathrm{~T}\end{array}$ & $\begin{array}{c}100 \mathrm{mCi}(* * *) \\
30 \mathrm{mCi} \\
1 \mathrm{mCi}\end{array}$ & $\begin{array}{l}\text { Beta Beam Room } \\
\text { Beta Beam Room } \\
\text { Beta Beam Room }\end{array}$ \\
\hline $\begin{array}{l}{ }^{60} \mathrm{Co} \\
137 \mathrm{Cs} \\
252 \mathrm{Cf}\end{array}$ & $\begin{array}{l}5 \mathrm{Ci} \\
10.5 \mathrm{Ci} \\
10 \mu \mathrm{g}\end{array}$ & $\begin{array}{l}\text { Gamma \& Neut. Well } \\
\text { Gamma \& Neut. Well } \\
\text { Gamma \& Neut. Well }\end{array}$ \\
\hline${ }^{137} \mathrm{Cs}$ & $1 \mathrm{mCi}$ & Envr. Testing Lab \\
\hline${ }^{3} \mathrm{H}$ & $\begin{array}{c}\text { GASEOUS SOURCES } \\
600 \mu \mathrm{Ci}\end{array}$ & Tritium Room \\
\hline${ }^{239} \mathrm{Pu}$ & $\begin{array}{l}\text { ELECTROPLATED SOURCES } \\
\qquad 8 \mu \mathrm{Cj}(* * * *)\end{array}$ & Alpha \& Beta Room \\
\hline X-Rays & GENERATED SOURCES & $X$-ray Beam Room \\
\hline
\end{tabular}

$(*) \quad(\mathrm{C}=$ Curic). The standard unit in measuring radioactivity, equal to the quantity of any radioactive material in which the number of disintegrations per second is $3.7 \times 10^{10}$.

(**) $\quad\left(\mu=\right.$ micro). The unit of measure used to express the form of one millionth part of; the factor $10^{-6}$

(***) $\quad(\mathrm{m}=\mathrm{milli})$. The unit of measure used to express the form of one thousandth part of; factor or $10^{-3}$.

(****) Maximum total activity of all 50 electroplated sources. 
The proposed calibration facility would have the following areas: gamma beam laboratory, low scatter laboratory, panoramic irradiator laboratory, beta beam laboratory, gamma \& neutron well, tritium laboratory, alpha \& beta laboratory, $x$-ray laboratory, central control room, performance testing and evaluation laboratory, radiation counting laboratory, receiving and decontamination room, wrapping and quality control room, Electrical and Instrumentation (E\&I) shop, machine shop, conference room, records room, vehicle bay, offices, heating ventilation and air conditioning equipment room, rest rooms/locker rooms, and storage rooms.

Facility construction would require "tie-in" to the B Area domestic water system, electrical supply grid, fire suppression water system, and domestic sewer system. Line Item 91-D-145, New Whole Body Counter Facility, would extend B Area utilities wo the west side of SRS Road \#2 providing tie-in points for this facility. Liquid effluent from the facility rest room sinks, commodes, water fountain drain, laboratory sink drains, and a lunchroom sink drain would be directed to the sanitary sewer. The roof, parking lot, and grounds would lead rainwater runoff to a storm sewer.

\subsubsection{Process}

The proposed calibration facility would provide a central site location for the SRS Instrument Calibration Program. The new calibration facility would also provide procurement, testing, and evaluation services for all new SRS radiation monitoring equipment. A typical routine for the new calibration facility would be as follows. Instruments requiring service would be picked up with a facility vehicle and delivered to the proposed calibration facility. Upon arrival, the subject instruments would be logged in with a bar code scanner and surveyed for radioactive contamination (decontamination would occur as necessary). Instruments being returned for repair would be forwarded to the E\&I shop for Central Services Works Engineering personnel to repair. Some types of instruments returned for routine calibration would have a set of "As Found" readings taken utilizing an appropriate source to determine if the response of the instrument was within required limits. The instrument would then be taken to the E\&I shop for maintenance. Following maintenance, the instrument would be calibrated and delivered to the user organization.

\subsection{Alternative Actions}

\section{2 .1 No Action}

An alternative to the proposed action is to take no action. In accordance with the National Environmental Policy Act (NEPA: 40 CFR 1502.14(d)), the "No Action" alternative is included to provide a baseline condition from which to evaluate the potential environmental impacts of the proposed action. This alternative, by definition, would consist of DOE-SR taking no action to construct a new calibration facility or to upgrade the existing SRS Instrument Calibration Facility so that it complied with existing DOE orders. This would result in a failure to meet both the purpose and need for agency action.

\subsubsection{Renovate the Existing Calibration Facility}

An alternative to constructing a new facility would be to renovate the existing calibration facility. This is not considered as an acceptable alternative as renovation is neither practical nor cost-effective. The existing facility is too small to provide space for all of the equipment necessary to meet DOE Orders 5480.4 and 5480.11. Renovation of the existing facility is also not considered as a practical alternative because the walls contain asbestos. Modifications to walls containing asbestos would be difficult and costly. This facility is further restricted by the amount of shielding and electrical supply. Given the nature of the safety concerns, and cost associated with renovation of the existing facility, it is not considered to be a reasonable option. 


\subsubsection{Expansion of the Existing Calibration Facility}

An alternative to constructing a new facility would be the expansion of the existing calibration facility. This is not considered to be an acceptable alternative because expansion of the existing facility is hampered by too many mitigating factors. Existing roads, underground utilities, and buildings adjacent to Building 736-A preclude construction of an annex. This facility is further restricted by its physical location to a surrounding working populace. Given the nature of the severe growth restrictions associated with the existing facility, expansion is not consider as a reasonable alternative.

\subsubsection{Alternative Construction Sites}

Another alternative to the proposed action was the construction of the proposed facility in the SRS 700 Area. The 700 Area is composed of the SRS Administration Area (A Area), the Savannah River Technology Center (SRTC), the Savannah River Ecology Laboratory (SREL), and the Fuel and Target Fabrication Facility (M Area). This proposal was initially examined for the convenience of having the proposed facility located in the same general area as the existing instrument calibration facility. However, due to space limitations with the 700 Area and elevated background radiation levels associated with the operation of SRTC and the Fuel Fabrication Facility, it was determined that the proposed facility would be better served by locating it away from operational Radiologically Controlled Areas (RCAs). Accordingly, this alternative was not considered as favorable "s the proposed action in providing an optimum setting for the operation of the proposed instrument calibrawon facility.

\subsubsection{Use of Offsite Calibration Facilities}

Another possible alternative to the proposed action is the use of offsite vendors to perform the calibration of SRS instrumentation. This alternative was investigated and considered to be an unreasonable option for the following reasons:

- A major project objective, complying with DOE Order 5480.4 and the DOE Radiological Control Manual (DOE/EH-(256T), could not be met. These documents require that instrument calibrations be performed in accordance with ANSI N323. No commercial facilities have to date been identified that could comply fully with the ANSI N323 instrument calibration requirements. The nearest fully qualified DOE calibration facility was determined to be at the Hanford Site.

- Offsite calibration organizations were not capable of providing timely support for emergency situations where the demand for instrument services can be very high.

- The existing contract with Eberline Instruments, Columbia, SC, was established primarily for calibration of the 124 high-range gamma instruments which could not be adequately calibrated using current SRS irradiators. This contract is expensive and difficult to manage because of the high resource loading of Calibrations staff needed to support it. The cost for the first 13 months of the contract was $\$ 45,956$. The total cost for similar partial services for the remaining 5,000 portable radiation monitoring instruments in the SRS inventory would be proportionately higher (approximately $\$ 1.7 \mathrm{M}$ per year). Several additional weeks are added to the turnaround time (one week for in-house services) for each instrument in order to accommodate the SRS reql irements for:

- Thoroughly monitoring each instrument for contamination and clearing them for offsite shipment.

- Preparing the paperwork for shipping and receipt.

- Performing QC verifications using SRS gamma irradiators for each instrument following vendor calibration.

- Performing the time consuming Subcontract Technical representative functions required to support the contract.

- Transporting instruments to/from the vendor's facility using SRS staff and vehicles.

- Coordinating accounting duties to verify invoice accuracy and to authorize payments. 
- In order to ensure the availability of an adequate supply of calibrated instruments to support routine SRS operations, the current inventory would need to be increased significantly because of the larger number of instruments that would not be in service at any given time.

- Most instruments used at SRS require repairs prior to recalibration. Because instrument manufacturers provide repair services only for their own equipment the SRS program would still require a dedicated instrument repair staff.

\subsection{AFFECTED ENVIRONMENT}

A comprehensive discussion of SRS and associated environs is presented in the Reactor Operation Environmental Impact Statement (ROEIS) (DOE, 1990), and in the Peactor Operation Environmental Information Documents, Volumes I-III (WSRC, 1989a, 1989b \& 1989c).

\subsection{Geography, Demography, and Socioeconomics}

The SRS encorr passes approximately 80,535 hectares (ha) $(199,000$ acres) in southwestern South Carolina. The SRS bordels the Savannah River for about $27 \mathrm{~km}(17 \mathrm{mi})$. Figure 3.1 shows SRS in relation to major population centers, with the closest being Augusta, Georgia, and Aiken and Barnwell, South Carolina. Figure 3-1 also shows the six-county area of South Carolina and Georgia where approximately 83 percent of the current SRS work force resides. In 1988, the six-county population was 425,000 including a six county region work force of 191,364. In 1989, approximately 15,000 SRS workers, or about 8 percent of the available work force, resided in the six-county area. The ROEIS (DOE, 1990) and the most recent socioeconomic survey of the six-county SRS area of influence (NUS, 1990) conta:n additional information.

The proposed actions subject for review under this EA would occur in B Area of SRS. B Area is depicted in relation to SRS in Figure 3-2. The proposed facility would be located on a 1.2 ha plot immediately adjacent the developed portions of B Area. This location is approximately $4.4 \mathrm{~km}$ from the nearest SRS site boundary.

\subsection{Meteorology and Climatology}

The SRS has a temperate climate with mild winters and long summers. The region is subject to continental influences, but is protected from the more severe winters in the Tennessee Valley by the Appalachian Mountains to the north and northwest. Gently rolling hills with no unusual topographic features that would significantly influence the general climate characterize SRS and the surrounding area. The meteorological and climatological data for SRS contained in this section are representative of that for the proposed Health Protection Instrument Calibration Facility location. The Reactor Operation Environmental Information Document, Volume III, (WSRC, 1989c) contains additional information on SRS meteorology and climatology.

\subsubsection{Average Wind Speed and Direction}

The average wind speed for the period of 1982 to 1986 , from onsite data, was 3.25 meters per second (m/s) $(10.66 \mathrm{ft} / \mathrm{s})$. Hourly wind speeds less than $2 \mathrm{~m} / \mathrm{s}(6.5 \mathrm{fv} / \mathrm{s})$ occurred about 9 percent of the time. For about half of the time, wind speeds were less the $4 \mathrm{~m} / \mathrm{s}(13.1 \mathrm{ft} / \mathrm{s})$. From 1975 to 1979, from onsite data, the average wind speed was greatest during the wirter $(3.35 \mathrm{~m} / \mathrm{s})$ and least during the summer $(2.48 \mathrm{~m} / \mathrm{s})$.

Data collected from $\mathrm{H}$ Area, which is near the center of SRS, indicate that observed wind directions tend to favor the southwest and northeast quadrants (28 and 30 percent of the time, respectively) in relation to the northwest (20 percent) and southeast (22 percent) quadrants. For all data, winds from the northeast sector occurred most frequently (nearly 10 percent of the time). That is, emissions would have been transported toward the southwest more frequently than toward any other direction. Winds from direction sectors in the southwest quadrant also occurred with a relatively high frequency ( 7 to 8 percent of the time) (DOE, 1990). 


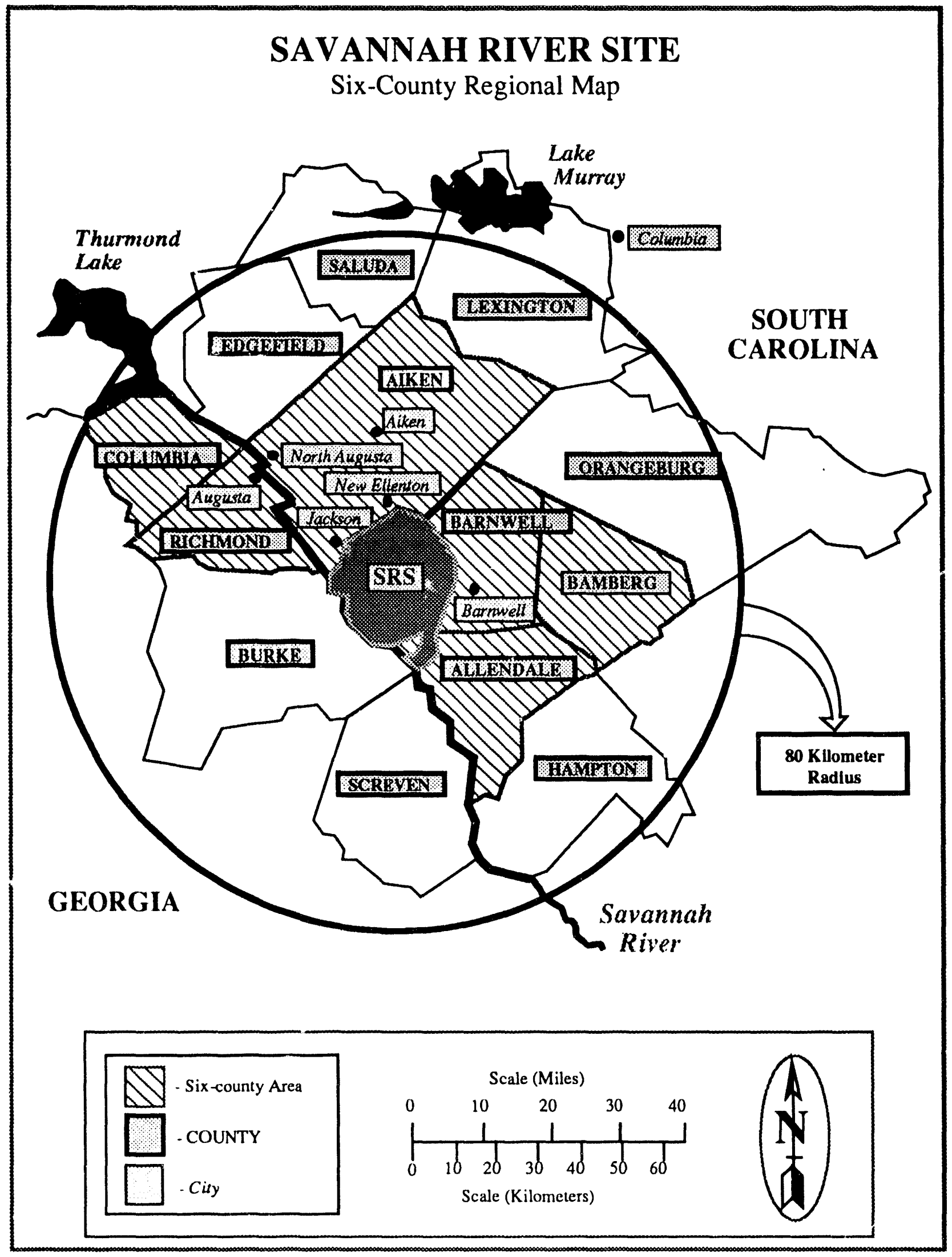

Figure 3-1. SRS in Relation to Surrounding Populations Centers 


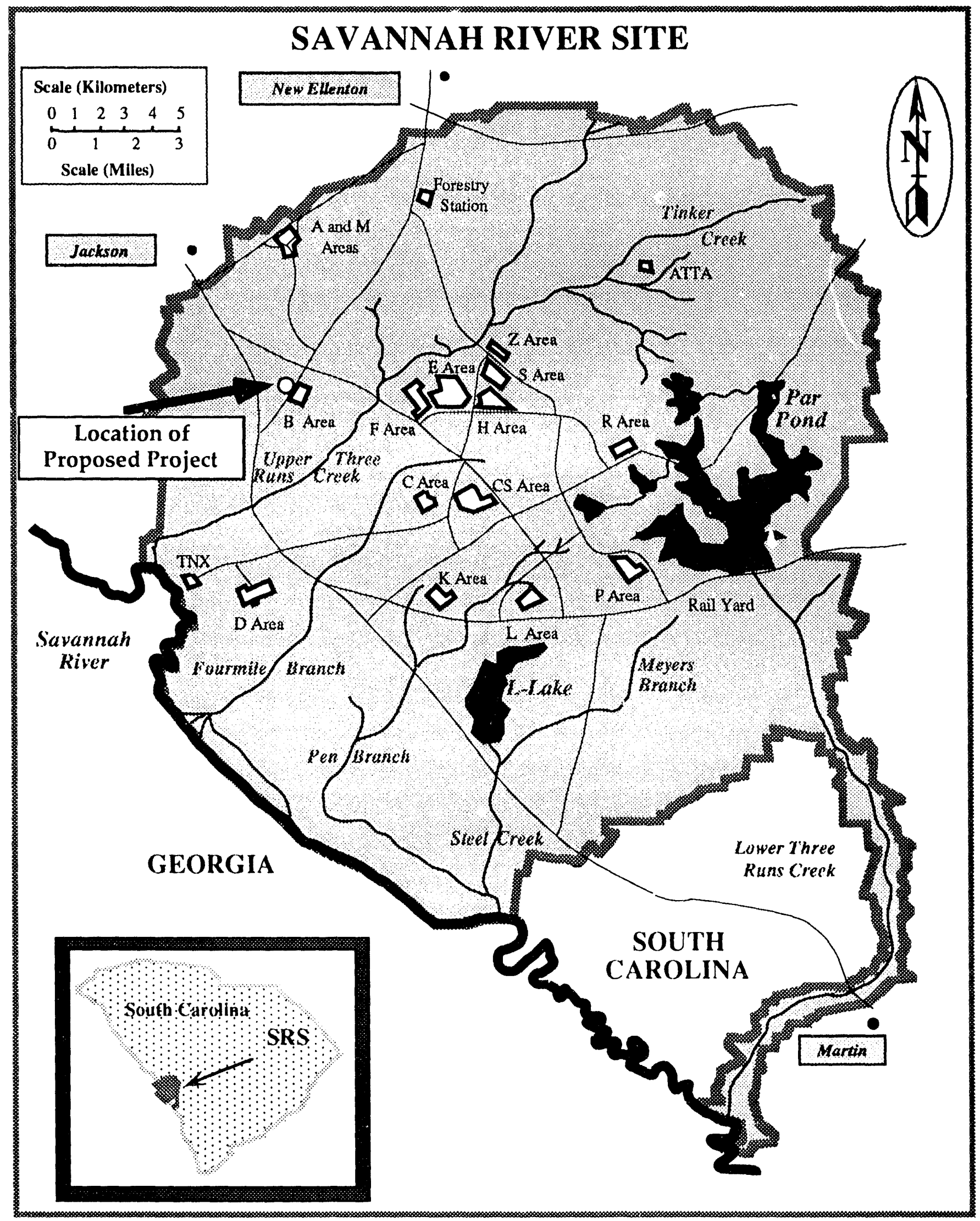

Figure 3-2. Location of B A rea on SRS 


\subsubsection{Precipitation}

The annual average precipitation for SRS (from 1952 through 1987) was about 122 centimeters (cm) (48 in). Precipitation is fairly well distributed throughout the year. However, average precipitation totals for the fall months (September, October, and November) are less than the average totals for the other seasons. These three months account for about 18 percent of the average annual total. Precipitation totals greater than $0.025 \mathrm{~cm}(0.009 \mathrm{in})$, occurred on average, about 107 days per year. The calculated 24 -hour $/ 100$-year rainfall at $S R S$ is $20.8 \mathrm{~cm}(8.18 \mathrm{in})$ (DOE, 1990).

\subsubsection{Tornadoes}

No damage has ever been done to a SRS production facility as a result of a tornado. However, tornadoes have been observed during every month of the year in the SRS area. Most of the tornadoes resulting in severe or devastating damage occurred in March, April, and May. Since SRS operations began, six confirmed tornadoes have occurred on or close to SRS. With the exception of the most recent tornado (October 1, 1989), only light to moderate damage resulted on each of these occasions. The October 1,1989 tornado caused considerable damage to SRS timber resources on about 444 ha (1,097 acres), and lighter damage on about 606 ha (1,497 acres). These damages occurred in a swath $23 \mathrm{~km}(14 \mathrm{mi})$ long on the east side of SRS. Investigations of tornadoes occurring near SRS in 1975 to 1976 indicated wind speeds between 173 and $281 \mathrm{~km} / \mathrm{hr}$ (107 and $175 \mathrm{mph}$ ) (DOE, 1990).

\subsection{Geology and Seismology}

\subsubsection{Physiography}

The SRS is located on the Aiken Plateau of the Upper Atlantic Coastal Plain physiographic province of western South Carolina, approximately 40 to $48 \mathrm{~km}(25$ to $30 \mathrm{mi})$ southeast of the Fall Line that separates the Atlantic Coastal Plain and the Piedmont provinces. The Coastal Plain province is underlain by a wedge of seaward-dipping unconsolidated and semi-consolidated sediments that extended from the Fall Line to the continental shelf. Subdivision of the Coastal Plain Province in South Carolina includes the Aiken Plateau, the Congaree Sand Hills, and the Coastal Terraces. The Congaree Sand Hills trend along the Fall Line north-northeast of the Aiken Plateau. The Aiken Plateau, wnere SRS is located, is bounded by the Savannah and Congaree rivers and extends from the Fall Line to the Coastal Terraces. The surface of the plateau is highly dissected and characterized by broad interfluvial areas with narrow, steep-sided valleys. The plateau is well drained, although poorly drained depressions do exist (WSRC, 1989a).

\subsubsection{Topography and Drainage}

The proposed calibration facility site is on the Aiken Plateau in the central SRS region. The plateau which slopes generally southeastward, is dissected by creeks that drain into the Savannah River. The major tributaries which occur on SRS are discussed in Section 3.4. The topography at the proposed calibration facility location reveals that the facility would sit on a topographic high (a ridge top), with surface drainage to the east and west into the Upper Three Runs Creek basin (USGS, 1987). The proposed location is well drained and flooding is not considered a hazard.

Ground surface elevation for the proposed calibration facility location is approximately $91 \mathrm{~m}$ ( $300 \mathrm{ft}$ ) above mean sea level across the proposed layout (USGS, 1987). The soil type at the proposed calibration facility location is Orangeburg loamy sand. The Orangeburg soil association consists of well drained, moderately permeable soils that typically have 0 to 2 percent slope (SCS, 1990).

\subsubsection{Geohydrology}

The sediments of the Atlantic Coastal Plain of South Carolina overlie the basement complex composed of Paleozoic crystalline and Triassic age rocks. These sediments dip gently seaward from the Fall Line and range in age from Late Cretaceous to Recent. Coastal Plain sediments in the vicinity of SRS consist of sandy clays and clayey sands, although occasional beds of clean sand, gravel, and clay occur. Two 
bioclastic limestone zones occur within the Tertiary age sequence. These calcareous zones vary in thickness

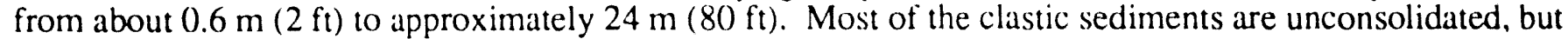
thin semi-consolidated beds also occur. The many formations that make up the layers may be grouped into several different permeable zones (aquifers) separated by mostly impermeable clay layers (confining units). Groundwater is abundant and of excellent quality in this region of South Carolina. The depth to groundwater at the proposed calibration facility location is approximately $40 \mathrm{~m}$ (130 ft) (WSRC, 1989b). At SRS, properly designed and completed wells are capable of producing thousands of gallons of water per minute. The Reactor Operation Environmental Information Document, Volume I, (WSRC, 1989a) contains recent information on SRS geohydrology make-up.

\subsubsection{Geologic Structures}

The closest offsite fault system of significance is the Augusta Fault Zone, approximately $40 \mathrm{~km}(25 \mathrm{mi})$ from SRS. In this fault zone, the Belair Fault has experienced the most recent movement, but is not considered capable of generating major earthquakes (Case, 1977). There is no conclusive evidence of recent displacement along any fault within $322 \mathrm{~km}(200 \mathrm{mi})$ of SRS, with the possible exception of the buried faults in the epicentral area of the 1886 Charleston, SC earthquake. The proposed calibration facility location does not overlap any of the known geologic faults on SRS (WSRC, 1989b).

\subsection{Hydrology}

The Savannah River forms the western boundary of SRS and receives drainage from five major tributaries on SRS: Upper Three Runs Creek, Four Mile Branch, Pen Branch, Steel Creek, and Lower Three Runs reek. These tributaries receive varying types of wastewater discharges from plant processes and sanitary treatment systems, all of which are permitted through the National Pollutant Discharge Elimination System (NPDES). On SRS various plant processes also require pumpage of Savannah River water and/or onsite groundwater. The Reactor Operation Environmental Information Document, Volume III (WSRC, 1989c) contains information on groundwater systems on SRS and in the surrounding region. No wetlands or streams are found on or within the immediate area of the location of the proposed calibration facility (Gladden, 1990).

\subsection{Ecology}

Since 1951 when the U. S. government acquired SRS, forestry management practices and natural succession outside the construction and operating areas at SRS have resulted in an increased ecological complexity and diversity of the site. Forested areas support a diversity of wildlife habitats that are restricted from public use. Forestry management practices include controlled burning, harvesting of mature trees, and reforesting. Wildlife management includes protection and enhancement of threatened and endangered species and population control of white-tailed deer (Qdocoileous virginianus) and wild swine (Sus scrofa) through supervised hunts.

The SRS, which was designated as a National Environmental Research Park in 1972, is one of the most extensively studied environments in this country. The Reactor Operation Environmental Information Document, Volume II, (WSRC, 1989b) contains additional information on the biotic characteristics of SRS.

The management and utilization of SRS forests, soils, watershed, and wildlife are detailed in the SRS Natural Resources Management Plan (DOE, 1991) and defined under the terms of a Memorandum Of Agreement (MOA) between DOE-SR, the Savannah River Forest Station (SRFS), the Soil and Conservation Service (SCS), and the Westinghouse Savannah River Company (WSRC). DOE-SR uses this MOA to define the roles and responsibilities of the various agencies and organizations in the management of natural resources on SRS. 


\subsubsection{Vegetation}

The vegetation across SRS represents a wide spectrum of the regional flora. The differing elevations, ground moisture levels, drainage rates, and proximity to wetlands across SRS create vastly differing areas of vegetation. On dry soil and sandy ridges the canopy is often dominated by turkey oaks (Quercus laevis), blue-jack oaks (Quercus incana Bartram), and black-jack oaks (Quercus marilandica), with longleaf pine (Pinus palustris Miller) present in various densities. In less xeric areas, oaks and hickories are also present. Understory species in the drier areas include hollies, lespedezas, and various lichens. On mid- and lower slopes, the mixed deciduous forests include tulip tree (Liriodendron tulipifera L.), black gum (Nyssa sylvatica Marshall), sweet gum (Liquidambar styraciflua L.), and red maple (Acer rubrum L.), as well as hickory and holly. Understory species on the more mesic sites includes vacciniums, hollies, various ferns, grapes, sassafras (Sassafras albidum), and dogwood (Cornus florida L.) (WSRC 1989b).

The location for the proposed calibration facility is in a currently undeveloped portion of B Area on SRS. The vegetation at the proposed location is composed primarily of dominant evergreen species, a 37-year old planted slash pine (Pinus elliotti) plantation, with a mixed pine and hardwood mid-story. Since the acquisition of SRS by the Federal Government in the early 1950s, this proposed location has historically been used for timber production by the United States Forest Service.

\subsubsection{Wildlife}

Of the diverse number of faunal species found on SRS, ten are afforded protection by the Federal Government under the Endangered Species Act of 1973. These protected species include the bald eagle (Haliaeetus leucocephalus), the golden eagle (Aquila chrysaetos), the wood stork (Mycteria americana), the red-cockaded woodpecker (Picoides borealis), the peregrine falcon (Falco peregrimus), the American osprey (Pandion Haliaetus), the kirtland warbler (Deudrocia Kirtlandii), the American alligator (Alligator mississippiensis), the shortnose sturgeon (Acipenser brevirostrum), and the brother spike mussel (Elliptio fraterna). None of these species have been documented on or near the proposed calibration facility location (WSRC, 1989b).

The vegetative homogeneity (pine plantation) that exists throughout much of the proposed calibration facility location provides for a relatively poor wildlife habitat. Species that would be expected to occur in the vicinity of the proposed site include gray squirrel (Sciurus carolinensis), fox squirrel (Sciurus niger), gray fox (Urocyon cineroargenteus), white-tailed deer (Odocoileus virginianus), bobcats (Felis rufus), opossums (Didelphins marsupialis), and various species of small rodents, songbirds, and reptiles.

\subsubsection{Threatened and Endangered Species}

The SRS provides habitat or transient habitat for 10 species of threatened or endangered animals, and 31 species of threatened or endangered or rare plants (Knox and Sharitz, 1988). Of these 41 species, only the red-cockaded woodpecker occurs in the vicinity of the proposed site. The red-cockaded woodpecker was included in the federal list of endangered species in 1970. Its decline is due primarily to a reduction in available nesting habitat (Lennartz and Henry, 1984). The red-cockaded woodpecker is a native of southern pine forests of the United States, nesting in cavities excavated in living trees. The birds use many species of pines, preferring older trces, usually over 70 years, and may actively select trees suffering from heart rot. Trees in most colonies are within a $457 \mathrm{~m}(1,500 \mathrm{ft})$ diameter area in open stands of pine with sparse midstories. Living pines are also the preferred foraging habitat for red-cockaded woodpeckers. A clan of redcockaded woodpeckers requires 51 ha (125 acres) of well stocked pine or pine-hardwood stands over 30 years old for survival and productivity. Timber harvest practices throughout the south generally result in pines being harvested for timber or pulpw'ood when the trees are less than 30 years old. The scarcity of old growth pines has resulted in a scarcity of suitable nesting habitat for the red-cockaded woodpecker.

The SRS contains 35 colony sites of four different categories. The SRS has four active colonies that contain productive clans, seven inactive sites that supported active colonies within the last ten years, abandoned sites that supported active colonies more than ten years ago, and recruitment sites containing appropriate habitat (Austin, 1989). 
The proposed calibration facility location is located within $15.8 \mathrm{~km}(9.8 \mathrm{mi})$ of an active red-cockaded colony. The proposed site was the subject of a formal Biological Evaluation (B.E.) performed by SRFS to address the possible impact on the adjacent colony. Due to the colony's distance from the proposed calibration facility location, no impact is expected on the colony from the construction or operation of the facility (Roecker, 1992).

\subsection{Radiation Environment}

Natural radiation sources contribute about 315 mrem per year, or 83 percent of the annual radiation dose of 379 mrem received by an average person residing in SRS regional area from all sources. Radiation received from medical diagnosis and therapy contributes about 54 mrem per year, or 15 percent, of this annual radiation dose. Consumer products contribute almost 10 mrem per year or slightly less than 3 percent of the annual dose. The SRS releases contribute less than 0.46 mrem or less than 0.09 percent of this total annual dose to the average individual within $80 \mathrm{~km}(50 \mathrm{mi})$ of SRS. For 1990 , the calculated maximum individual annual dose at SRS boundary from atmospheric releases averaged $0.06 \mathrm{mrem}$. The 1991 Savannah River Site Environmental Report. (WSRC, 1992a) contains additional information on specific contributing radiation sources.

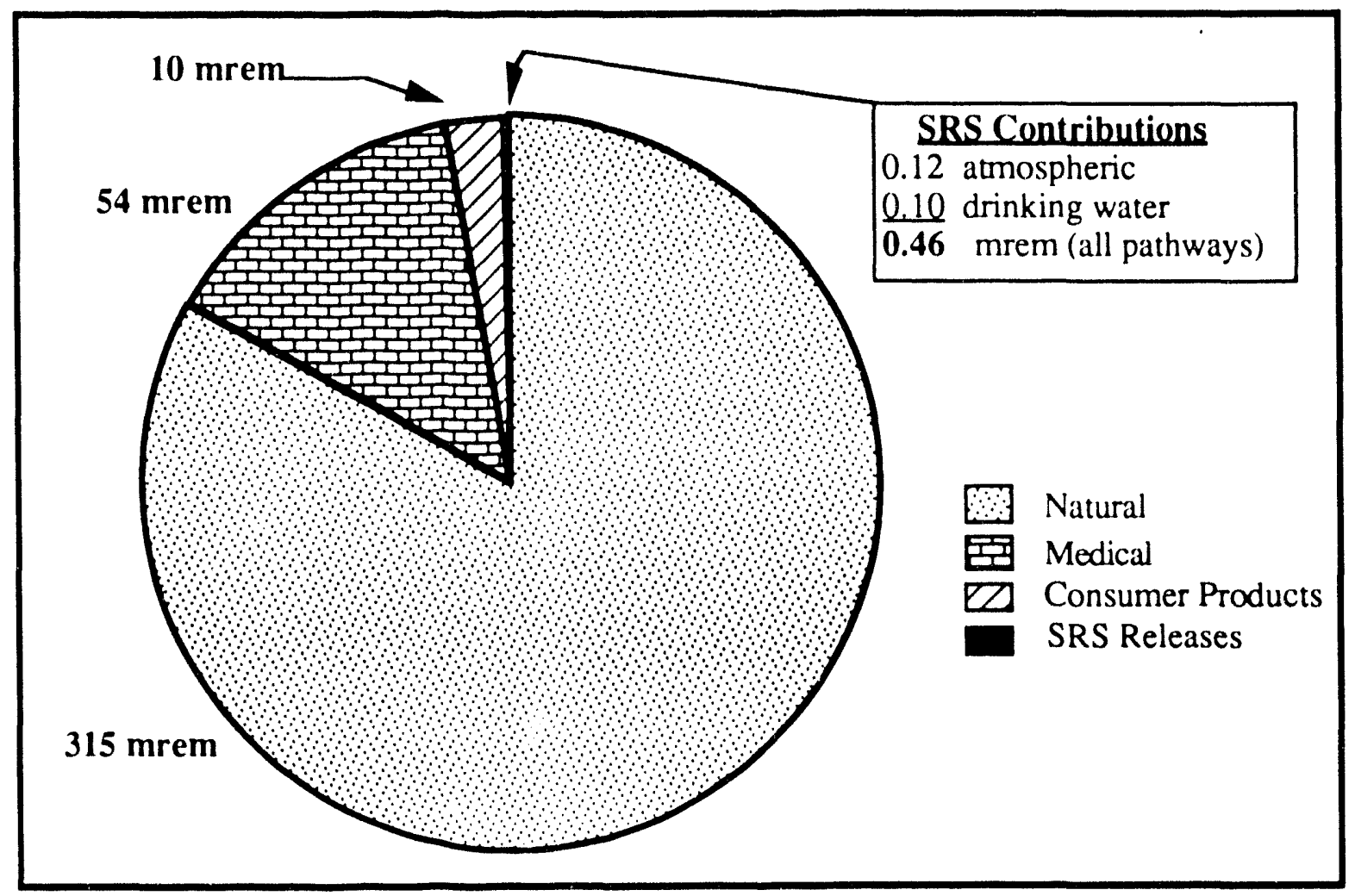

Figure 3-3. SRS Regional Radiological Dose

\subsection{Waste Management}

The SRS generates liquid, solid, and semisolid wastes originating in reactor and support facility operations, maintenance, and renovation activities. These wastes include those held in storage, pending treatment or disposal, and wastes from closure or remediation activities at existing waste sites. The Final EIS. Waste Management Activities for Groundwater Protection, Savannah River Plant, (DOE, 1987) describes waste 
generation rates, management facilities, treatment methods, and management capacity. In 1987, DOE initiated a comprehensive waste management program following the analysis of a preferred waste management strategy (DOE, 1987).

All waste management activities on SRS are guided by the "Federal Sector Pollution Prevention Control Strategy" and by DOE policy on Waste Minimization and Pollution Prevention as identified in DOE-HQ EH25 memorandum "Integrating Pollution Prevention with NEPA Planning Activities", (DOE, October 15, 1992).

\subsection{ENVIRONMENTAL CONSEQUENCES OF THE PROPOSED ACTION}

\subsection{Construction and Normal Operation}

\subsubsection{Land}

The proposed Health Protection Instrument Calibration Facility would be constructed ard operated in B Area of SRS, in what is now an undeveloped location. The proposed facility would be located on a 1.2 hectare (ha) site, on the west side of SRS Road \#2. This facility would be located within a general site bounded by north coordinates N87502.53 to N88463.04 and east coordinates E38953.92 to E40447.17. The location for the proposed Health Protection Instrument Calibration Facility is included in a DOE-SR approved Site Use Permit (SU-89-54-C Amendment \#5; Hill, 1992) for the proposed 5 year footprint for the B Area Engineering Center Campus and in the current development plans for B Area (Zeigler, 1988). Amendment \#5 of this site use permit which specifically addresses the area to be used by the proposed Instrument Calibration Facility, indicated no interferences with other land uses in the area. Conditions of this permit were that buildings must maintain a minimum 10 -foot radius from monitoring wells; erosion control plans should be in place for construction; and a program plan must be prepared if a new water supply well is to be constructed.

Currently, 93 percent of SRS remains undeveloped (WSRC, 1989b). The 1.2 hectares to be cleared for the proposed facility represents the development of less than 0.002 percent of the total undeveloped SRS land area. The proposed project would be compatible with other land uses in B Area.

\subsubsection{Socioeconomics}

The socioeconomic impact of the proposed project could be broken down into two phases. The first would come from construction, and the second from normal operations. The construction of the proposed facility would be carried out by a fixed price contractor. The contract workers would comprise fewer than 100 specialists, who would be brought onto SRS for installation of major facility construction. This work force would be drawn from both local and non-local sources as determined by skilled worker availability. The proposed construction workforce would comprise less than $0.5 \%$ of the total SRS workforce.

Once completed, the proposed facility would be operated with a staff of fewer than 35 personnel. The staff of the new calibration facility (technicians, managers, maintenance personnel, administrators, etc.) would be composed of personnel who are already employed in the existing SRS calibration facility. Thus, there would be no socioeconomic impact associated with normal operations.

\subsubsection{Air Quality}

Construction related air quality effects fall within two areas: equipment use and soil disturbance. Diesel operated equipment (trucks, backhoes, and other diesel powered support equipment) would be used to haul soil and other solid wastes for disposal, for excavation, and in the performance of other routine construction activities. The operation of this class of equipment does not currently fall within the South Carolina Department of Health and Environmental Control (SCDHEC) requirements for air permitting activities. The environmental affects from the purchase and use of such equipment at SRS has been previously addressed and found to be individually and cumulatively not significant by DOE and is documented in two Categorical Exclusions (SR/CX9003015 and SR/CX9003025 both dated June 25, 1990). 
- Facility construction would result in some soil disturbance. The minimization and mitigation of this - potential source would be covered under an approved Erosion Control Plan for the project.

- After facility startup, the only radioactive material that would be released into the atmosphere would be i-itium $\left({ }^{3} \mathrm{H}\right)$. The annual amount of ${ }^{3} \mathrm{H}$ released into the atmosphere would be approximately $200 \mu \mathrm{Ci}$, at a rate of approximately $4 \mu \mathrm{Ci}$ per week. This release of ${ }^{3} \mathrm{H}$ would fall well within the limits established by DOE Order 5400.5 of 100 mrem per year. Currently all SRS releases account for only 0.46 mrem annually (WSRC, 1992a).

\subsubsection{Groundwater and Surface-Water Resources}

The proposed actions would not require the development of any new groundwater or surface water resources. The only groundwater resources which would be utiliced in connection with this activity would be domestic water supplies for use as drinking water and sanitary sewer supplies, and fire water for use in charging the buildings fire suppression systems. All domestic waters would be permitted through SRS Area Facilities Coordinators and SCDHEC.

No surface water would be used during operation of the proposed facility. All domestic and fire water would be obtained from existing B Area water wells and delivered through existing distribution systems. The domestic water needs of the proposed facility are not expected to exceed 30 gallons per minute (gpm), and should not affect the water level of the supply aquifer. The fire water usage for this facility is normally expected to be zero gpm.

There would be no impact on SRS wetlands. As part of the routine SRS Site Use Permit system, each prospective site is reviewed for ecological impact. These reviews are conducted by the Savannah River Technical Center (SRTC). The review covers wetlands, groundwater and surface water resources (Gladden, 1990).

A review of the proposed calibration facility location has determined that there are no wetlands associated with the proposed location. The nearest wetland (a Carolina Bay) is more than $2.4 \mathrm{~km} \mathrm{(1.5} \mathrm{mi)} \mathrm{away.}$ Accordingly, there would be no infringement upon, or loss of wetlands. Some soil disturbance would occur as a result of the construction activities related to this project. The minimization and mitigation of this potential source would be covered under an approved Aiken County Erosion Control Plan for the project. Typical met' ods employed at SRS include such things as: the use of silt fences to prevent transport of sediment; the seeding of soil stockpiles to prevent erosion; and the development of siltation basins to trap sediments in construction site runoff.

\subsubsection{Waste Management}

The construction of the proposed calibration facility would result in the generation of some construction related deu.is. This debris would be disposed of in the SRS Sanitary Landfill or Erosion Control Pit. Since the proposed location lies in a previously undeveloped area, no contaminated soils or waste sites are expected to be encountered during construction. Aside from small amounts of domestic sanitary waste, no new waste streams would be generated from this facility as it is designed to replace an existing waste generator.

Besides the usual office and domestic waste items, the primary solid waste produced by the proposed calibration facility would be low-level radioactive waste (LLW). LLW consists of such items as shoe covers, rubber gloves, paper, and tape having contamination levels less than 250,000 disintegration per minute/100 square centimeters $\left(\mathrm{dpn} / 100 \mathrm{~cm}^{2}\right)$. This LLW would be collected in radioactive waste boxes which would be subsequently shipped for processing and disposal in welded steel boxes of 2.5 cubic meters $\left(\mathrm{m}^{3}\right)$ capacity known as B-25s. 
The projected volume of LLW to be generated at the calibration facility as a result of routine operations is 4 $\mathrm{m}^{3}$ per year. This volume represents about 0.01 percent of the approximate $30,980 \mathrm{~m}^{3}$ of LLW generated at SRS on an annual basis (DOE, 1990). This volume of LLW does not represent an increase in waste volume as the proposed facility would replace an existing calibration facility (i.e., a LLW generator). Existing LLW management facilities at SRS were designed to handle wastes generated by all SRS facilities. Therefore, there would be no additional burden on SRS waste handling capability by implementation of the proposed action.

The very small quantities of hazardous waste (rags saturated with lubricating oil, acetone, or alcohol) and radioactive mixed wastes (saturated rags used in decontamination of calibration instruments) associated with the proposed action would be handled in accordance with RCRA guidelines.

In all cases, the actions of the construction and operational work forces associated with this project would be guided by the Federal Sector Pollution Prevention Policies. To demonstrate the intent of the Federal Government as the national leader in pollution prevention policies and practices across all missions, activities, and functions, the workforces associated with the proposed action would;

- prevent or reduce pollution at the source wherever feasible.

- recycle in an environmentally safe manner the pollution that cannot be prevented.

- treat in an environmentally safe manner the pollution that cannot be prevented or recycled.

- dispose of pollution only as a last resort.

The project team's commitment to these federal guidelines would ensure DOE compliance with existing pollution prevention and control policies.

\subsubsection{Radioactive and Hazardous Materials}

Radiological doses to the offsite population for all SRS 1991 atmospheric releases have been estimated to be 7.1 person-rem, and $6.0 \times 10^{-3} \mathrm{rem}$ to the off site maximally-exposed individual (WSRC, 1992). The proposed action would not result in any increased exposure to the offsite population, as the proposed facility is designed to replace an existing facility. Improvements in facility design, shielding, air filtration, and relocation of the calibration facility to a more centralized SRS location should result in a net decrease in the radiological doses to the on- and offsite population.

Exposure of operating personnel to radiation during normal operations is monitored by the SRS Health Protection Department. Exposure includes both external radiation and inhalation or ingestion of radionuclides. Radiation dose rates at the proposed facility shall be ALARA (As Low As is Reasonably Achievable) and shall not exceed $0.25 \mathrm{mrem} / \mathrm{hr}$ on the average to personnel continuously occupying controlled areas. At SRS "continuously occupied areas" are assumed to be occupied 2,000 hour per year. The design dose rate would ensure that the maximum annual individual dose rate to the staff in the new facility would be significantly less than $500 \mathrm{mrem}$. In comparison, maximum annual dose to individual staff members in the existing facility has been approximately $390 \mathrm{mrem}$ (Polz, 1993). Based on an occupational risk factor of $4 \times 10^{-4}$ fatal cancers per person-rem, workers engaged in this proposed project would not be expected to incur any harmful health effects from radiation exposures they receive during normal operations. Normal operating procedures require that operating personnel wear dosimeters, which measure the radiation exposure received while on SRS. Individual exposures are limited to and maintained below $2 \mathrm{rem} / \mathrm{yr}$ wholebody. However, the entire SRS has established individual area ALARA (As Low As Reasonably Achievable) and Reference Level Goals which are well below the 2 rem/yr limit and reestablished each year.

Those radioactive calibration sources currently being used in the 736-A facility would be relocated to the new calibration facility. The additional sources listed below would be required to be purchased in order for the proposed calibration facility to comply with DOE Orders and ANSI Standards. These new sources would represent an increase of $25 \%$ of the total number of sources being used in the existing calibration facility.

$60 \mathrm{Co}:(6,000), 75,20$, and $1 \mathrm{Ci})$

$137 \mathrm{Cs}:(5,000), 100,62,20,20,2.2,1.2,0.5$, and $0.001 \mathrm{Ci})$

$252 \mathrm{Cf}:(4,0.3,0.03$, and $0.01 \mathrm{mg})$ 
Some of the personnel working in the proposed calibration facility may be working with the hazardous chemicals/materials listed in Table 4-1. These workers would be trained in the proper handling and precautionary measures to be taken when working with these materials. Workers would be fully trained and educated (OSHA Material Safety Data Sheets) on the specific health hazards associated with each of the materials listed in Table 4-1. In all cases workers would be required to wear the protective clothing and equipment appropriate for the material at hand (WSRC Manual 4Q, Industrial Hygiene).

The chemicals to be used in the proposed calibration facility would be present in quantities well below the reportable quantities listed in 40 CFR Part 302.

Table 4.1

Hazardous Chemicals/Materials

\begin{tabular}{ccc}
\hline \hline SOURCE & AMOUNT & FORM \\
\hline Alcohol & 1 gallon & liquid \\
Acetone & 1 gallon & liquid \\
Lubricating Oils & 1 gallon & liquid \\
\hline
\end{tabular}

\subsubsection{Archaeological and Cultural Resources}

Cultural resources at SRS are managed under the terms of a Programmatic Memorandum of Agreement (PMOA) among DOE-SR, the South Carolina State Historic Preservation Officer (SHPO), and the Advisory Council on Historic Preservation (DOE, 1990a). DOE-SR uses this PMOA to identify cultural resources, assess these in terms of National Register eligibility, and develop mitigation plans for affected resources in consultation with the SHPO. DOE-SR would comply with the stipulations of the P..OA for all activities related to the construction and operation of the proposed instrument calibration facility.

As part of the routine SRS Site Use Permit system, each prospective site is reviewed for archaeological impact. These reviews are conducted by the University of South Carolina Archaeological Department. This review resulted in the determination that the proposed facility would have no impact on SRS archaeological resources. The proposed calibration facility location has also been reviewed under the Archaeological Resource Management Plan of the Savannah River Archaeological Research Program (December 1989) and determined to be in the lowest, or Class III, area of archaeological concern. No impact on SRS archaeological or cultural resources is expected from the construction and operation of the proposed facility.

\subsubsection{Ecology}

As part of the routine SRS Site Use Permit system, each prospective site is reviewed for ecological impact. These reviews are conducted by SRTC and SRFS. The review covers threatened and endangered species, rare plants, and pristine biotic areas. In addition, a formai Biological Evaluation (B.E.) was conducted on the proposed site. The findings from the B.E. stated that no sensitive habitats were found within the immediate area selected for the calibration facility, and threatened and endangered species or their habitats would not be affected. No endangered species have been identified in the vicinity of the proposed calibration facility location from this or any previous SRS biological surveys. The habitats in the vicinity of the project location are not suitable for any of the federally protected species that have been identified for SRS, except for the red-cockaded woodpecker. The distances to the nearest active and inactive colonies for the red-cockaded woodpecker from the proposed project location are $15.8 \mathrm{~km}(9.8 \mathrm{mi})$ and $4.8 \mathrm{~km}(3.0 \mathrm{mi})$, respectively. The proposed calibration facility location is beyond the typical foraging distance for this species as reported on SRS. Accordingly, the proposed action would not have an effect on endangered species or their habitats (Roecker, 1992 \& Gladden, 1990). The findings of the B.E. were also forwarded to the United States Fish and Wildlife Service (USFWS) in Charleston, South Carolina for review and approval. The USFWS concurred with the findings of the B.E. and concluded that the proposed action was "Not likely to adversely affect listed or proposed endangered species." (USFWS, 1992). 
The proposed action would result in the harvesting of some marketable timber (roughly 3,100 board feet of marketable timber) during site preparation and clearing. This clearing represents less than 0.003 percent of SRS planted pine plantations. The proposed action would not affect any sensitive areas, such as floodplains, wetlands, habitats of state or federally listed threatened or endangered species, sole-source aquifers, and cultural resources.

\subsubsection{Mitigation}

The only mitigation action which would be required in conjunction with the proposed action is the preparation, approval, and implementation of an erosion control plan. All erosion control plans used on SRS must follow the format as established in the Aiken County Erosion Control Ordinance. Once prepared this plan must be screened by the U.S. Soil and Conservation Service (SCS) Field Office and approved by DOE-SR prior to any construction activity. During project construction, site inspections by the WSRC Environmental Protection Department and SCS personnel would be conducted to ensure compliance with the Erosion Control Plan.

\subsection{Accident Analysis}

\subsubsection{Non-radiological Consequences}

Prior to facility operation the Calibration Facility would be required to formulate appropriate emergency procedures for the evacuation of facility personnel in the event of an emergency (fire, tornado, etc.). These procedures would ensure that there would be no loss of life, or unnecessary radiological dose associated with a facility emergency or destruction.

The risk of a process accident as the result of a natural disaster (i.e., earthquake, flood, tornado) was examined. The risk of a building strike from a tornado was determined to have the greatest risk for natural disasters. Statistics (Ramsdell and Andrew, 1986) show reports of 37 tornadoes from 1954 to 1983 for a 1 degree square of latitude and longitude that includes SRS. This is an average of about one tomado per year. Based on data for this 30-year period, the estimated average frequency of a tornado striking any given location in South Carolina was $7.11 \times 10^{-5}$ per year. This results in a point-strike recurrence interval of about once every $14,()(X)$ years. A direct strike by a tornado would result in total facility destruction and possible fatalities to the building's occupants.

Fire was also determined to pose a threat to the proposed facility. However, the proposed facility would be protected with an automatic fire detection and suppression system. The detection system would be connected to the SRS central alarm system. In the event of fire detector activation, the alarm would be sounded at the nearest SRS Fire Station (in F Area) which is $4.9 \mathrm{~km}(3.1 \mathrm{mi})$ away. The suppression system to be installed in the proposed facility would comply with all National Fire Protection Association (NFPA) standards for this type of facility. All NFPA life safety requirements would also be met. A large fire frequency has been determined by utilizing the approach that, at SRS, the frequency of a large fire is $6.05 \times 10^{-5}$ per year per 10,000 square feet of facility (Paddleford, 1991). The proposed Instrument Calibration Facility would occupy approximately 22,00 stjuare feet thus yielding a large fire frequency of $1.33 \times 10^{-5} / \mathrm{yr}$. Based on the facility design and anticipated compounds to be used during normal operations, explosions associated with the proposed facility are not possible.

\subsubsection{Radiological Consequences}

The amount of fissile material to be louated in the proposed facility would be well below the critical mass for each isotope (see Table 4-2). Thus, a criticality hazard does not exist in the proposed facility (Nadeau, 199()). 


\section{Table 4.2}

Potential Criticality Hazard Sources

\begin{tabular}{cc}
\hline SOURCE & AMOUNT OF MATERTAL \\
\hline Sealed Sources: & $5.11 \mathrm{mg}{ }^{252} \mathrm{Cf}$ \\
Electroplated Sources: & $0.013 \mathrm{mg} 239 \mathrm{Pu}$ \\
\hline
\end{tabular}

The maximum potential dose which could be experienced by an on- or offsite individual (1.44 REM and $6.57 \times 10^{-3}$ REM respectively) involves an extremely unlikely scenario in which the proposed calibration facility is burned to the ground, melting the electroplated sealed sources, allowing release of the entire radiological inventory. Such an event would result in a postulated release at the proposed facility which is summarized in Table 4-3. The radiological dose calculations are based on airborne radioactivities, without any credit for engineered features or administrative controls (i.e., fire suppression, structural fire barriers, storage of calibration sources in shielded, fire proof vault, etc.). A Source Reduction Factor (SRF) of 0.(O)(O53 is used for the radioactive sources in the facility, except for the tritium in the Tritivin Room, where a SRF of 1.0 is used. The SRF given in NUREG (1988) for the burning of a contamirated combustible powder is 0.00053 .

In the event of a tornado strike, resulting in total facility destruction, the resulting dose to the on- and offsite population would be less than that which would be received from a fire (see Table 4-3). The resulting dose would be lessened as many of the source materials are electroplated onto metal discs. Without a fire to melt the electroplated metals, the source material would be released as a 'unit' to the environment and not scaltered for maximum dispersion.

Both on- and offsite radiological doses were calculated using the AXAIR-89Q computer code (Nadeau, 199()). The calculations use the following parameters;

- Onsite receptors are located downwind at a distance of 100 meters $c$.

- Offsite receptor is located at the site boundary in the worst meteorological sector.

- Release duration is two hours.

- Site-specific atmospheric dispersion factors are employed from the current meteorological database.

- All releases are assumed to be at ground level. Building wake effects or plume-terrain interactions were conservatively not considered.

- ICRP-30 dose factors in AXAIR-89Q are employed.

The airborne radiological source term is the activity listed in Table 2-1 multiplied by the SRF. The calculated doses resulting from each source being released are shown in Table 4-3. The computed doses for a maximum exposed individual at the site boundary and within the site at 100 meters are $6.57 \times 10^{-3}$ and $1.44 \mathrm{rem}$, respectively (Nadeau, 1990)

It is not possible to translate the doses given in Table 4-3 into an accurate Health Effects section as to date scientists have not measured the health effects from doses this low.

c In accordance with the Interim Hakards Guide for Non-Reactor Facilities al he Savannah River Site, (WSRC, 1990), 'onsite' dose is conservatively computed for workers located at 100 meters and down wind of the subject facility. 
Table 4.3

Radiological Dose from Accident

\begin{tabular}{|c|c|c|c|}
\hline NUCLIDE & $\begin{array}{l}\text { AMOUNT } \\
\text { RELEASED TO } \\
\text { ATMOSPHERE } \\
\text { (Ci) }\end{array}$ & $\begin{array}{c}\text { MAXIMUM } \\
\text { DOSE } \\
100 \begin{array}{l}\text { METERS } \\
\text { (REM) }\end{array}\end{array}$ & $\begin{array}{l}\text { MAXIMUM } \\
\text { DOSE AT } \\
\text { SITE BOUNDARY } \\
\text { (REM) }\end{array}$ \\
\hline \multicolumn{4}{|c|}{ GAMMA BEAM ROOM } \\
\hline${ }^{60} \mathrm{Co}$ & 3.530 & 0.911 & $4.17 \times 10^{-3}$ \\
\hline${ }^{137} \mathrm{Cs}$ & 2.942 & 0.162 & $7.33 \times 10^{-4}$ \\
\hline Total & 6.472 & 1.073 & $4.90 \times 10-3$ \\
\hline \multicolumn{4}{|c|}{ LOW SCATTER ROOM } \\
\hline${ }^{60} \mathrm{Co}$ & $1.06 \times 10^{-2}$ & $2.73 \times 10^{-3}$ & $1.25 \times 10^{-5}$ \\
\hline${ }^{137} \mathrm{Cs}$ & $1.70 \times 10^{-2}$ & $9.35 \times 10^{-4}$ & $4.23 \times 10^{-6}$ \\
\hline $252 \mathrm{Cf}$ & $1.62 \times 10^{-3}$ & 0.361 & $1.64 \times 10^{-3}$ \\
\hline Total & $\begin{array}{l}2.92 \times 10=2 \\
\text { PANORAMIC I }\end{array}$ & $\begin{array}{c}0.365 \\
\text { IATOR ROOM }\end{array}$ & $1.66 \times 10 \cdot 3$ \\
\hline${ }^{137} \mathrm{Cs}$ & $6.36 \times 10^{-4}$ & $3.50 \times 10^{-5}$ & $1.58 \times 10^{-7}$ \\
\hline \multicolumn{4}{|c|}{ TRITIUM ROOM } \\
\hline${ }^{3} \mathrm{H}$ & $\begin{array}{c}6.00 \times 10^{-4} \\
\text { GAMMA AND NE }\end{array}$ & $\begin{array}{c}9.78 \times 10^{-8} \\
\text { ON WELL ROOM }\end{array}$ & $4.44 \times 10^{-10}$ \\
\hline${ }^{60} \mathrm{Co}$ & $2.65 \times 10^{-3}$ & $6.84 \times 10^{-4}$ & $3.13 \times 10^{-6}$ \\
\hline${ }^{137} \mathrm{Cs}$ & $5.57 \times 10^{-3}$ & $3.06 \times 10^{-4}$ & $1.39 \times 106$ \\
\hline $252 \mathrm{Cf}$ & $3.18 \times 10^{-6}$ & $7.09 \times 10^{-4}$ & $3.21 \times 10^{-6}$ \\
\hline Total & $\begin{array}{r}8.22 \times 10^{-3} \\
\text { ALPHA AN }\end{array}$ & $\begin{array}{l}1.70 \times 10^{-3} \\
\mathrm{TA} \operatorname{ROOM}\end{array}$ & $7.73 \times 10-6$ \\
\hline${ }^{239} \mathrm{Pu} / \mathrm{Be}$ & $4.24 \times 10^{-9}$ & $3.72 \times 10^{-6}$ & $1.68 \times 10^{-8}$ \\
\hline \multicolumn{4}{|c|}{ PERFORMANCE AND ENVIRONMENTAL TESTING LAB } \\
\hline \multicolumn{3}{|c|}{ BETA BEAM ROOM } & $1.32 \times 10^{-10}$ \\
\hline$\left.{ }^{9}\right)_{\mathrm{Sr}} / \mathrm{Y}$ & $5.30 \times 10^{-5}$ & $1.18 \times 10^{-4}$ & $5.35 \times 10^{-7}$ \\
\hline $147 \mathrm{Pm}$ & $1.59 \times 10^{-5}$ & $9.30 \times 10^{-7}$ & $4.21 \times 10^{-9}$ \\
\hline${ }^{204} \mathrm{TI}$ & $5.30 \times 10^{-7}$ & $2.09 \times 10^{-9}$ & $9.49 \times 10^{-12}$ \\
\hline Total & $6.94 \times 10 \cdot 5$ & $1.19 \times 10^{-4}$ & $5.39 \times 10 \cdot 7$ \\
\hline FAC & TOTAL & 1.44 & $6.57 \times 10-3$ \\
\hline
\end{tabular}

\subsection{Cumulative Impact}

The principal cumulative impact from the construction and operation of the proposed project would be the loss of 1.2 hectares of planted pine plantation habitat (@3,100 board feet of marketable timber). Currently, 93 percent of SRS remains undeveloped (WSRC, 1989b). The proposed action represents the development of less than 0.002 percent of the total undeveloped SRS land area. Table 4-4 summarizes the effects of the proposed project. In addition, operation of the proposed facility would add approximately $200 \mu \mathrm{Ci}$ of tritium into the atmosphere on an annual basis. 


\section{Table 4.4}

\section{Summary of Potential Impacts}

IMPACT SUBJECT

\section{ENVIRONIMENTAL CONSEQUENCES}

Land

Socioeconomics

Ecology

Cultural Resources

Radiation/Occupational Safety

Waste Management

Air Quadity

Transportation
The Proposed Action would result in the clearing and development of 1.2 hectares ( 3 acres) of planted pane plantation. This comprises less than $(0 .(X) 3$ percent of SRS pine plantations. The proposed project would be compatible with other land uses in B Area.

Facility construction and operation would not result in any direct or indirect socioeconomic impact to the SRS regional area.

Facility construction and operation would not result in any adverse affect to SRS ecological (e.g., threatened and endangered species, fish/wildlife habitat, and wetlands) resources.

Facility construction and operation would not result in any adverse affect on the cultural/historical resources of SRS.

Facility operations in a Radiologically Controlled Area (RCA) would be undertaken in accordance with the SRS radiation control procedures (such as Manual 5Q. Radiological Control) and would result in a radiation exposure to workers that falls within established lower administration guidelines and DOE limits for occupational exposure of $5 \mathrm{rem} / \mathrm{yr}$. In accordance with the WSRC Radiological Improvement Plan (WSRC, 1992) individual personnel exposure would be limited to $2 \mathrm{rem} / \mathrm{yr}$ through work controls. Work in RCAs would bi carried out by workers trained in the proper procedures for the location and situation involved.

As a result of the new facility, overall worker exposure to radiation would experience a net decrease due to increased shielding and facility compliance with existing DOE orders governing radiation saffety (i.e., DOE 5480.11). Occupational safety would also increase as the new facility would incorporate the latest DOE and OSHA safety designs.

Facility construction and operation would not result in the creation of any new waste streams. The proposed facility is designed to replace an existing facility which is not capable of complying with DOE Order 5480.4 or DOE Order 5480.11 .

Facility operations would result in the annual release of $200 \mu \mathrm{Ci}$ of tritium (approximately $4 \mu \mathrm{Ci}$ per week) to the atmosphere. The proposed action would not result in any increased exposure to the offsite population, as the facility is designed to replace an existing facility. Improvements in facility design, shielding, air filtration, and relocation of the calibration facility to a more centralized SRS location should result in a net decrease in the radiological doses to the on- and offsite populations. These doses fall well within the routine safety levels for normal operations, as governed by DOE Order 54()0.5 (Radiation Protection of the Public and Environment). This Order limits doses to $100 \mathrm{mrem}$ per year from all sources and pathways from routine DOE operations.

Onsite transportation is not expected to be impacted by construction or routine operation of the proposed facility. 


\section{Table 4-4 (Cont'd)}

\section{Summary of Potential Impacts}
IMPACT SUBJECT
ENVIRONMENTAL CONSEQUENCES

Accident Analysis

In the event of a catastrophic accident (fire, etc.) in which the entire radiological inventory of the proposed facility were released into the surrounding environment, radiation doses to onsite workers $(100 \mathrm{yds})$ and offsite populace (site boundary) would be 1.4 rem and $6.57 \times 10^{-3}$ rem respectively.

Cumulative Impacts The principal cumulative impact would be the loss of 1.2 hectares of pine plantation habitat (@3,100 board feet of marketable timber).

\subsection{REGULATORY AND PERMITTING PROVISIONS CONSIDERED}

DOE policy is to perform its operations in compliance with all existing applicable federal, state, and local laws and regulations, and with all DOE orders. This section discusses the major regulatory programs that are applicable to the proposed action.

\subsection{National Environmental Policy Act of 1969}

NEPA, as amended (42 USC $4321 \mathrm{et}$ seq), requires "all agencies of the Federal Government" to prepare a detailed statement on the environmental effects of proposed "major federal actions significantly affecting the quality of the human environment." This EA was prepared to assess the significance of the environmental effects of the proposed Instrument Calibration Facility and to comply with NEPA, the Council on

- Environmental Quality Regulations on Implementing National Environmental Policy Act (40 CFR 15001508), DOE National Environmental Policy Act: Implementing Procedures; Final Rule and Notice 10 CFR

1021, and DOE Order 544().1E.

\subsection{Solid Waste Regulations}

Small quantities of miscellaneous non radioactive, non hazardous scrap from construction operations would be disposed in the SRS Solid Waste Landfill. During routine operations, miscellaneous trash (e.g., office waste paper, maintenance shop waste) would also be disposed in the landfill.

Any radioactive solid waste that would be generated would be subject to the requirements of DOE Order 5820.2. "Radioactive Waste Management".

Disposal of mixed waste (low-level radioactive hazardous waste) would be subject to the additional RCRA requirements and the South Carolina Hazardous Waste Management Regulations (SCHWMR) R.61-79.

\subsection{Air Emissions Regulations}

The projected annual release of $2(x) \mu \mathrm{Ci}$ of tritium (at a rate of approximately $4 \mu \mathrm{Ci}$ per week) falls within the emissions guidelines currenty established by DOE and SCDHEC.

\subsection{Domestic Water Regulations}

The domestic water tie-in for the toilets, sinks and showers requires a Public Water Works permit to be approved by the State of South Carolina (SCDHEC Regulation R61-58).

\subsection{Liquid Discharge Regulations}

Both the Sanitary Sewer Construction Permit (SCDHEC Regulation R61-67) and the Sanitary Sewer Operation NPDES Permit (SCDHEC Regulation R61-68) require approval by the State of South Carolina, prior to construction and operation of the proposed facility. 
A small quantity of waste solvents would be handled as a liquid hazardous waste. Present plans do not involve storing this waste at the generating facility for more than 90 days. All applicable requirements pertaining to hazardous waste (e.g., RCRA, SCHWMR r.61-79) would be met.

\subsection{Transportation Regulations}

Routine activities in the processing of radiation monitoring instrumentation could involve onsite transportation of potentially contaminated instruments from the field users to the proposed calibration facility. Such transportation would be in accordance with applicable regulations, including DOE Order 5480.3 (Safety Requirements for the Packaging and Transportation of Hazardous Materials, Hazardous Substances, and Hazardous Wastes). In addition, applicable requirements of the Nuclear Regulatory Commission (10 CFR Part 71) and the Department of Transportation (49 CFR 171-178) would be followed. State transportation requirements applicable to transportation of radioactive material to and from SRS (e.g., routing requirements) would be followed to the extent that such requirements are not inconsistent with Federal regulations.

\subsection{AGENCIES AND PERSONNEL CONSULTED}

This document was compiled in part from information contained in the Reactor Operation Environmental Impact Statement (DOE, 199()). Information was provided by, discussed with, and/or reviewed by personnel in the following organizations;

- U.S. Fish and Wildlife Service, Charleston Office (USFWS)

- Savannah River Forest Station (SRFS)

- University of South Carolina

- Department of Archaeology and Anthropology 


\subsection{REFERENCES}

Austin, R. S., 1989. Personal Communication Regarding Current Status of Red-Cockaded Woodpecker Colonies at SRS. Savannah River Forest Station, Aiken, South Carolina.

Case, E. G., 1977. Reports on Recent Fault Movements in the Eastern I'nited States, Memorandum SECY $.77-411$ to Commissioners of the U.S. Nuclear Regulatory Commission from the Office of Nuclear Reactor Regulation, Washington, D. C.

DOE (U.S. Department of Energy), 1987. Final Environmental Impact Statement, Waste Management Activities for Groundwater Protection, Savannah River Plant, DOE/EIS-0120, Savannah River Operations Office, Aiken, South Carolina.

DOE (U. S. Department of Energy), 1990. Final Environmental Impact Statement, Continued Operation of K-L- and P-Reactors, Savannah River Site DOE/EIS-0147, Savannah River Operations Office, Aiken, South Carolina.

DOE (U.S. Department of Energy), 1990a. Programmatic Memorandum of Agreement Among Savannah River Operations Office, U.S. Department of Energy. The South Carolina State Historic Preservation Officer, and the Advisory Council on Historic Preservation Concerning the Management of Archaeological sites on the Savannah River Site, Aiken, Allendale and Barnwell Counties, South Carolina. August 24, 1990. Savannah River Operations Office, Aiken, South Carolina.

DOE (U. S. Department of Energy), 1991. Intent to Prepare Programmatic Environmental Impact Statement for Reconfiguration of the Nuclear Weapons Complex, Federal Register 56 Fr 5590-5596.

DOE (U. S. Department of Energy), 1991a. Natural Resources Management Plan: Strategic Guidance for the Savannah River Site's Natural Resources Programs, Savannah River Field Office, Aiken, South Carolina.

Ferlic, K. P., et al., 1989. Health Physics Review, Savannah River Plant, Office of Environmental, Safety and Health, U. S. Department of Energy, Washington, D. C.

Gladden, J. B., 1990. Memorandum to J. S. Murdock, March 19, 1990, "Evaluation of SRS B-Area Facility Construction", SRL-ESS-90-(0359, Westinghouse Savannah River Company, Aiken, South Carolina.

Hill, H. G., 1992. Memorandum to D. W. Godbee, January 10, 1992, "Whole Body Counter, B-Area, Log No. 654", EPD-FSD-928037, Westinghouse Savannah River Company, Aiken, South Carolina.

Knox, J. N., and R. R. Sharitz, 1988. Endangered Threatened and Rare Vascular Flora of the Savannah River Plant, University of Georgia, Savannah River Ecology Laboratory, Aiken, South Carolina.

Lennartz, M. R., and V. G. Henry, 1984. Endangered Species Recovery Plan, Red-cockaded Woodpecker, (Picoides borealis), U. S. Fish and Wildlife Service, Region 4, Atlanta, Georgia.

Nadeau, M. A., 1992. Health Protection Instrument Calibration Facility Hazards Assessment Document (U), SRT-WAG-920()42, Savannah River Technology Center, Westinghouse Savannah River Company, Aiken, South Carolina.

Nadeau, M. A., 1993. Health Protection Instrument Calibration Facility Hazards Assessment Document (U) Rev. 1, SRTC-TR-92-435, Savannah River Technology Center, Westinghouse Savannah River Company, Aiken, South Carolina. 
NUREG (Nuclear Fuel Cycle Facility Accident Analysis Handbook), 1988. NUREG-1320, U. S. Nuclear Regulatory Commission, U. S. Depatment of Energy, Washington, D. C.

NUS (NUS Corporation), 1990. Socioeconomic Characteristics of Selected Counties and Communities Adjacent to the Savannah River Site NUS Report No. 5234, Savannah River Center, Aiken, South Carolina.

Paddleford, D. F. and Perdue, R. K., 1991. A Multi-Attribute Utility Analysis Model for Application to SRS Fire Protection Upgrade Prioritization (U). STC Document Number 91-9SJ1-MULI-R1, WSRCTR-91-469, Westinghouse STC, Pittsburgh, PA, February 1991.

Polz, E. J., 1993. Memorandum to P. Harmon and J. Harris, July 13, 1992. Westinghouse Savannah River Company, Aiken, South Carolina.

Ramsdell, J. V., and G. L. Andrews, 1986. Tornado Climatology of the Contiguous United States, U. S. Nuclear Regulatory Commission, NUREG/CR-4461, Washington, D. C.

Roecker, R., 1992. Biological Evaluation, Proposed Health Protection Instrument Calibration Facility Savannah River Site Savannah River Forest Station, U. S. Forest Service, Aiken, South Carolina.

SCS (Soil Conservation Service), 1990. Soil Survey of Savannah River Plant Area, Parts of Aiken. Barnwell, and Allendale Counties, South Carolina, U. S. Department of Agriculture, Soil Conservation Service, Aiken, South Carolina.

USFWS (U. S. Fish and Wildlife Service), 1992. Review of the Proposed Instrument Calibration Facility Site for Threatened/Endangered Species Concerns, USFWS Log No. 4-6-92-461, dated August 17, 1987. U. S. Fish and Wildlife Service, Charleston, South Carolina.

USGS (U. S. Geologic Survey), 1987. Savannah River Plant, 1:48,(0)() scale map, U. S. Geologic Survey, U. S. Department of the Interior, Reston, Virginia.

WSRC (Westinghouse Savannah River Company), 1989a. Reactor Operation Environmental Information Document, Volume 1: Geology, Seismology and Subsurface Hydrology (U), WSRC-89-815 Savannah River Site, Aiken, South Carolina.

WSRC (Westinghouse Savannah River Company), 1989b. Reactor Operation Environmental Information Decument, Volume II: Ecology (U), WSR.C-89-816 Savannah River Site, Aiken, South Carolina.

WSRC (Westinghouse Savannah River Company), 1989c. Reactor Operation Environmental Information Document, Volume III: Meteorology. Surface Hydrology. Transport and Impacts (U) WSRC-89-817, Savannah River Site, Aiken, South Carolina.

WSRC (Westinghouse Savannah River Company), 1990. Interim Hizards Classification Guide for NonReactor Facilities at Savannah River Site, ESH-SSE-90-0318, Kim, K. S. and Waltz, W. R., Savannah River Site, Aiken, South Carolina.

WSRC (Westinghouse Savannah River Company), 1992. Radiological Improvement Plan, Savannah River Site, Aiken, South Carolina.

WSRC (Westinghouse Savannah River Company), 1992a. Savannah River Site Environmental Report for 1991, WSRC-TR-92-186, Savannah River Site, Aiken, South Carolina.

Zeigler, C. C., 1988. Memorandum to W. C. Renig and G. Hayes, November 14, 1988, re: Proposed New Health Protection Complex in B-Area, Westinghouse Savannah River Company, Aiken, South Carolina. 


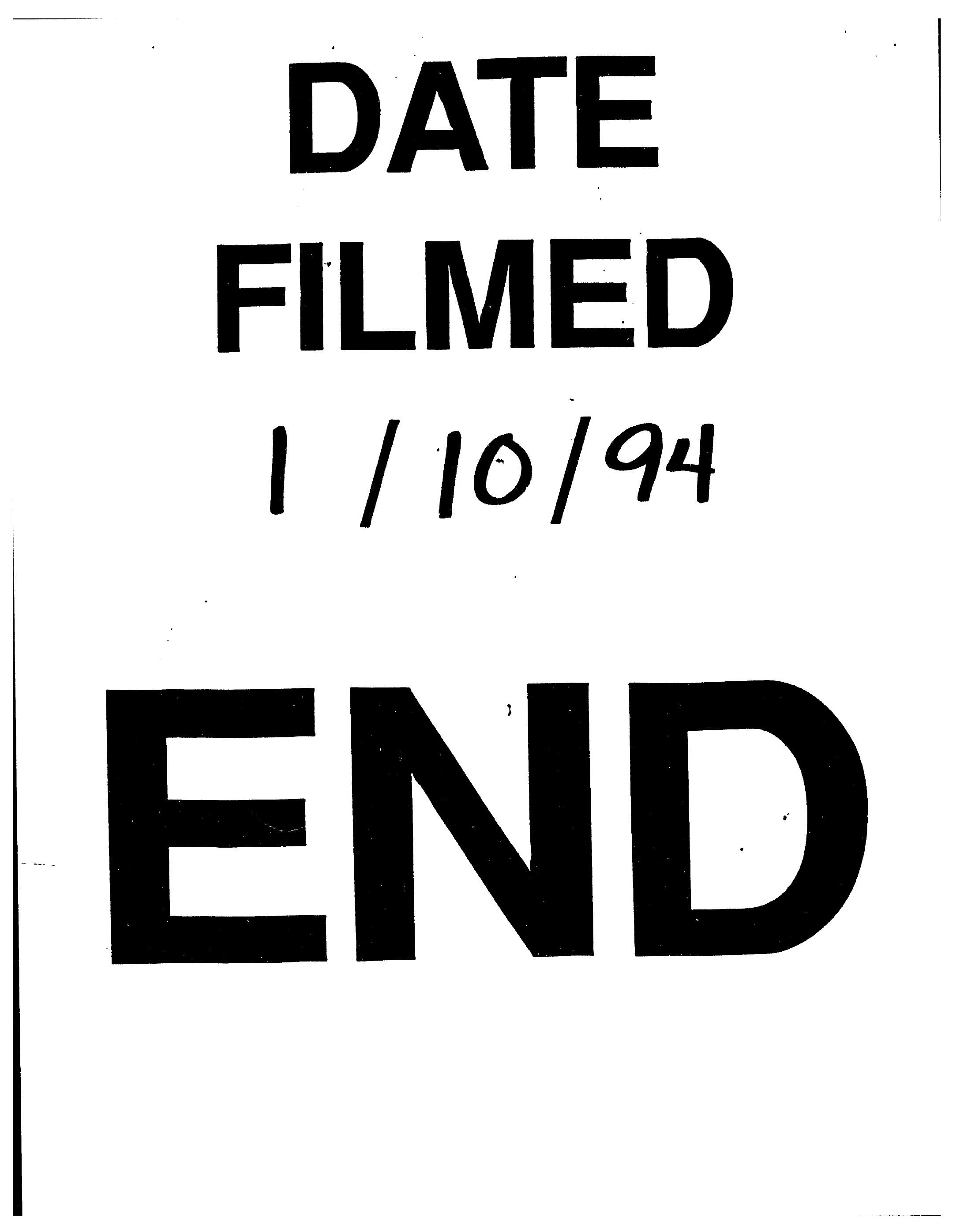


